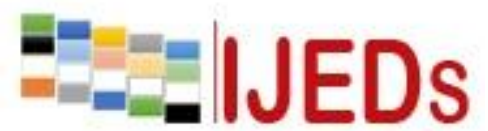

http://ijeds.ppj.unp.ac.id/index.php/IJEDS

\title{
THE INFLUENCE OF USING CONCEPT MAP THROUGH COOPERATIVE LEARNING THINK PAIR SHARE ON THE LEARNING OUTCOMES ON ELEVENTH GRADE SCIENCE STUDENTS OF SMAN 1 DUA KOTO PASAMAN
}

\author{
*Maiyesi Yenti ${ }^{1}$, Indang Dewata ${ }^{2}$, Mawardi $^{3}$ \\ ${ }^{1}$ Graduate Program of Educational Technology, Universitas Negeri Padang, Indonesia \\ ${ }^{2,}$ Chemistry Education, FMIPA, Universitas Negeri Padang, Indonesia \\ ${ }^{3}$ Chemistry Education, FMIPA, Universitas Negeri Padang, Indonesia \\ Email : maiyesi05@gmail.com
}

*Corresponding Author, Received: November 12, 2019, Revised: December 10, 2019, Accepted: December 21, 2019

\begin{abstract}
The research aims to study the effect of using concept map through cooperative learning Think Pair Share (TPS) on th learning outcomes on eleventh grade science students of SMAN 1 Dua Koto Pasaman in terms of students' initial knowledge. This was a quasy experiment. Sample are choose using cluster random sampling techniques. Data are analyzed using t-test. Based on the average value of student learning outcomes in the experiment group, $75 \%$ or 27 students have reached the minimum completeness criteria. The calculation of the hypothesis $t_{\text {count }}(3.042)>t_{\text {table }}(1.995)$, it is means $H_{o}$ rejected and $\mathrm{H}_{1}$ is received. It can be concluded that the learning outcomes of students taught using concept map through cooperative learning TPS signicantly different from learning outcomes of students taught with concept maps through conventional learning. The conclusion of this study are there is an effect of the use of concept map in cooperative learning Think Pair Share (TPS) on the learning outcomes on eleventh grade science student in SMAN 1 Dua Koto Pasaman.
\end{abstract}

\section{Keywords : Concept Map, Cooperatif Learning Think Pair Share, Learning Outcomes}

\section{INTRODUCTION}

Learning science requires basic concepts that are attempted to be built by students and independently developed, both through the transfer of knowledge and direct observation of natural phenomena. All of this will be processed cognitively and 


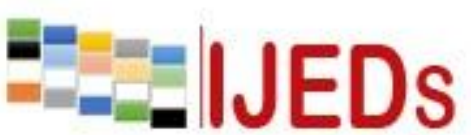

http://ijeds.ppj.unp.ac.id/index.php/IJEDS
International Journal of Educational Dynamics

Vol. 2 No. 1 (pp. 234-243) Desember 2019

p_ISSN 2655-4852

e_ISSN 2655-5093

will eventually produce behavioral changes. Constructivist approaches amphasize the process of consructing their own concepts learned by students. Chemistry lessons tend to be difficult subjects for students because one of the characteristics of chemistry is that most of concepts are abstract, such as atomic structure, chemical bonds and acid-base concepts. Chemistry subjects have certain characteristics, one of them is that the concepts in them are interrelated. Understanding one concept influences the understanding of the other concepts so that each concept must be mastered correctly.

The concept is an abstaction that describes the characteristics, characteristics or attributes of the same group of objects from a fact, whether it is a process, event, object or phenomenon in nature that distinguishes it from other groups. Whereas according to Zack and Tversky as quoted by Wibowo (2008), the concept is categories that classify the types of events and characteristics based on general property. Undestanding of a concept can develop well if first presented the most general concepts as a bridge between information that already exist in the cognitive structure of students ot on student knowledge. Related to understanding chemistry concepts, one of the causes of low student achievement in chemistry lessons in students' misconceptions of chemistry concepts. The impression of the chemistry as a difficult lesson is very influential on the attitudes, interests, and motivation of student learning.

During this time students SMA Negeri 1 Dua Koto Pasaman in the learning process are more likely to make notes in the form of long sentences and memorize them. Students cannot answer question if they don't match what they memorized, which means students lack understanding of the material they have learned. Therefore, it is necessary to be able to assist teacher in providing understanding in chemistry subjects. The selection of goog learning methods can influence success in improving students learning outcomes. Students in receiving subject matter need a tool that can be used in teaching and learning acrivities, one of which is the concept map.

Concept map is a creative note-taking activities that make it easy for students to remember lots of information. Novak in Dahar states that concept maps are tools or ways that teachers can use to find out what students already know. Novak's idea is based on the Ausubel learning theory which emphasizes so that the teacher knows the concepts that have been owned by students so that meaningful learning can take place. 


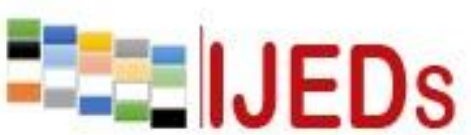

http://ijeds.ppj.unp.ac.id/index.php/IJEDS
International Journal of Educational Dynamics

Vol. 2 No. 1 (pp. 234-243) Desember 2019

p_ISSN 2655-4852

e_ISSN 2655-5093

In learning meaningful new knowledge must be linked to relevan concepts that already exist in the student cognitive structure (Trianto: 2007). If in the cognitive structure there are no relevant concept, new knowledge that has been learned is merely memorization.

The teacher can use the technique to record concept maps, by giving students the task of marking important concepts on teaching materials. Then the concepts are linked in the form of concept maps which will be made in groups (Asmaningrum: 2018). Students in their groups can discuss making concept maps and completing exercises from the materials being studied. Based on observations and an interview with one of the chemistry teacher in SMAN 1 Dua Koto Pasaman, it is known the teacher still uses the lecture method accompanied by question and answer (convensional) so that students are less active in learning. In addition, collaboration between students that can support the achievement of learning objectives is still low. Students tend to be busy taking notes and listening to lectures from the teacher alone, without any interaction with other students in building their understanding of chemistry concepts. These factors cause student achievement to be not optimal.

Based on the dailiy chemistry test scores for 2013/2014 school year, it can be seen that the average daily test scores of students for buffer solution material are still below the minimum completeness value specified, or about $55 \%$ of students complete. This show that students do not understand the material being taught. In addition, conventional methods that are still used by teachers in teaching cause students to be passive in the learning process. Student learning activities are low and sometimes there are students who are sleepy so the subject matter taught to students is not absorbed which results in students grades being low.

One of fasilities that can support the use of concept maps is cooperative learning. Cooperative learning refers to a variety of learning methods where students work in small groups to help one another in learning subject matter. In cooperative classes, students are expected to be able to help each other, discuss and argue with each other to hone the knowledge they have mastered at the time and close the gap in their understanding. One of type coopeative learning that can be used to evercome these problems is the use of cooperative learning think pair share (TPS). The selection of this learning model is due to low group activity in learning so it is boring and lacks 


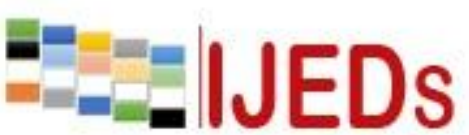

http://ijeds.ppj.unp.ac.id/index.php/IJEDS

enthusiasm. TPS is a learning model that allows students to be more active and take full responsibility for understanding te subject matter, both collectively and individually. This learning model helps students to think, pair up and share with classmates. Students practice their abilities by thinking from the material provided by the teacher, then they pair up with a classmate to share the subject matter, both collectively and individually. This learning models helps students to think, pair up and share with classmates. Students practice their ability to think from the subject matter given by the teacher, then they pair up with classmates to share with classmates to present the subject matter they have absorbed, so that the subject matter becomes a unified whole to be understood. Through this method the presentation of teaching materials is no longer boring because students are given time to discuss solving a problem together with their partners so that both students who are smart and those who are less clever together benefit through this learning activity. So during the teaching ang learning process it is expected that all students are active because in the end each student must pair up to share the results of the discussion in front of the class with other friends and student mastery of the subject matter can improve student learning outcomes.

Mastery of concept in students can be built by through a constructive learning process, starting from the introduction if students' initial knowledge in each cognitive structure generated with new knowledge gained in learning activities that the followed by students. Therefore, in this study the importance of students' initial knowledge will have an influence on student learning outcomes. The level of initial konwledge of students can be known by giving initial tests to students, but there are still many teacher who have not done this. This initial knowledgw test is very important to distinguish students who have high initial knowledge will find it easier to understand concepts so learning outcomes increase, while students with low knowledge will have little difficulty understanding subsequent concepts.

This study aims to look at the effect of the use of concept maps through cooperative Think Pair Share (TPS) on learning outcomes in buffer solution material in eleventh grade science students in SMAN 1 Dua Koto Pasaman in terms of students' initial knowledge. The use of concept map and learning models is tried because the concept maps and cooperative learning models of TPS have not been widely used by 


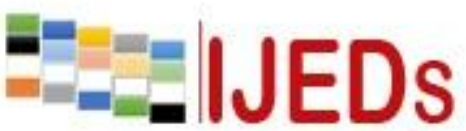

http://ijeds.ppj.unp.ac.id/index.php/IJEDS
International Journal of Educational Dynamics

Vol. 2 No. 1 (pp. 234-243) Desember 2019

p_ISSN 2655-4852

e_ISSN 2655-5093

teachers in chemistry learning, and pay attention to students' initial knowledge as a basis for knowing new knowledge.

\section{METHOD}

This type of research is a quasi experimental research. The population in this study were all students of eleventh grade science 2014/2015 academic year consisting of three classes. The sample in this study was taken from a population divided into two groups, namely the experiment class and control class. Determination of sample classes using cluster random sampling techniques. The sample is divided into two groups and the required samples are taken randomly. For the experiment class sample, learning uses concept maps through cooperative learning think pair share, and for the learning control class uses concept maps trough conventional learning. Both classes were held pretest before being given treatment to find out the student's initial knowledge, and posttest was given to see student learning outcomes after being given treatment.

\section{RESULTS AND DISCUSSION}

Data analysis of student learning outcomes is carried out to test whether the proposed hypothesis is accepted or rejected. Before testing the the hypothesis, first test the normality and homogeneity of the experiment class and control class. The normality unit aims to find out whether the two data groups are normally distributed or not. Homogeneity test aims to determine whether the two data have a homogeneous variance. Homogeneity test performed test performed is the Bartlett test.

3.1 Normality test and homogeneity test of the experiment and control class

The normality unit aims to find out whether the two data groups are normally distributed or not. Normality test is done by the Lilliefors test. Data are normally distributed at a significant level $\alpha=5 \%$. Test criteria are accept $\mathrm{H}_{\mathrm{o}}$ if $\mathrm{L}_{\text {count }}<\mathrm{L}_{\text {table }}$ and reject $\mathrm{H}_{\mathrm{o}}$ if $\mathrm{L}_{\text {count }}>\mathrm{L}_{\text {table. }} \mathrm{H}_{\mathrm{o}}$ sound are normally distributed data.

Table 1. Normallity test result of learning outcomes of the experiment and control class

\begin{tabular}{|c|l|c|c|c|}
\hline No. & \multicolumn{1}{|c|}{ Group } & $\mathrm{L}_{\text {count }}$ & $\mathrm{L}_{\text {table }}$ & Conclution \\
\hline 1. & Experiment class & 0,129 & 0,1477 & Normal \\
\hline 2. & Control class & 0,111 & 0,1477 & Normal \\
\hline 3. & High initial knowledge experiment class & 0,090 & 0,2000 & Normal \\
\hline 4. & Low initial knowledge experiment class & 0,138 & 0,2000 & Normal \\
\hline 5. & High initial knowledge control class & 0,115 & 0,2000 & Normal \\
\hline 6. & Low initial knowledge control class & 0,147 & 0,2000 & Normal \\
\hline
\end{tabular}




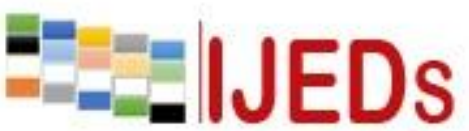

http://ijeds.ppj.unp.ac.id/index.php/IJEDS
International Journal of Educational Dynamics

Vol. 2 No. 1 (pp. 234-243) Desember 2019

p_ISSN 2655-4852

e_ISSN 2655-5093

Tabel 1 shows the normality of the experiment and control class, both overall and separately between high initial knowledge and low initial knowledge, all data are normally distributed because the value of $\mathrm{L}_{\text {count }}<\mathrm{L}_{\text {table }}$ for the significant level of $\alpha=$ $5 \%$. Homogeneity test aims to determine whether the two data have a homogeneous variance. Homogeneity test performed test performed is the Bartlett test.

Table 2. Homogeneity test result of learning outcomes students of experimnt and control class

\begin{tabular}{|c|l|c|c|c|}
\hline No. & \multicolumn{1}{|c|}{ Group } & $\mathrm{b}_{\text {count }}$ & $\mathrm{b}_{\text {table }}$ & Conclusion \\
\hline 1. & Experiment and control class & 0,9943 & 0,9513 & homogeneous \\
\hline 2. & High initial knowledge experiment and control class & 0,9285 & 0,8902 & homogeneous \\
\hline 3. & Low initial knowledge experiment and control class & 0,8914 & 0,8902 & homogeneous \\
\hline
\end{tabular}

3.2 The pretest and posstest result of the experiment and control classes.

Pretest is done to find out the initial ability of students before being given treatment and posttest is done to find out student learning outcomes after given learning treatment.

Table 3. Pretest data of experiment and control class

\begin{tabular}{|c|c|c|c|c|}
\hline Group & $\bar{X}$ & $\mathrm{~S}$ & $\mathrm{X}_{\max }$ & $\mathrm{X}_{\min }$ \\
\hline Experiment & 13,50 & 4,78 & 23 & 4 \\
\hline Control & 12,50 & 4,77 & 27 & 4 \\
\hline
\end{tabular}

Table 3 shows the average value pretest of the experiment and control class students is not much different, namely 13.50 and 12.50 . From this information it can be concluded that the experimental have relatively similar basic abilities.

Table 4. Posttest data of experiment and control class

\begin{tabular}{|c|c|c|c|c|c|c|}
\hline Group & $\bar{X}$ & $\mathrm{~S}$ & $\mathrm{X}_{\max }$ & $\mathrm{X}_{\min }$ & $\mathrm{t}_{\text {count }}$ & $\mathrm{t}_{\text {table }}$ \\
\hline Experiment & 79.17 & 11.15 & 100 & 58 & \multirow{2}{*}{3.042} & \multirow{2}{*}{1.995} \\
\cline { 1 - 5 } Control & 72.36 & 12.75 & 96 & 50 & & \\
\hline
\end{tabular}

Table 4 shows that the average value posttest of experiment class students who were taught using concept maps through TPS cooperative learning was higher than control class students who were taught using concept maps through conventional learning. Based on the average value of student learning outcomes in the experiment 


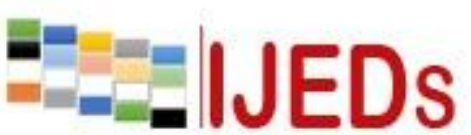

http://ijeds.ppj.unp.ac.id/index.php/IJEDS
International Journal of Educational Dynamics

Vol. 2 No. 1 (pp. 234-243) Desember 2019

p_ISSN 2655-4852

e_ISSN 2655-5093

group, $75 \%$ or 27 students have reached the minimum completeness criteria, and the control group of $58 \%$ or 21 students have reached the minimum completeness criteria.

In this learning, students do not make a complete concept map, but students complete the concept map provided by the teacher. Learning with concept maps guides students in understanding lessons through exiting concept. Students must understanding the material well to be able to complete the concept map provided by the teacher. Students who do not understand the material well cannot complete the concept map and make connections between concepts correctly. Concept map play an important role in shaping knowledge, where students will be able interpret the concept schemes on the concept maps.

The acquisition of average learning outcomes is quite high in the experiment group because the concept map is a way used to explore the cognitive structure of students and improve students' understanding of the subject matter they have read. The use of concept maps with cooperative learning TPS can improve student learning outcomes because it can encourage students to think more, discuss with partners, and share answers with classmates. Cooperative learning TPS provides an opprtunity for individual students to develop their own thinking because of the time to think. Then the answers they have thought about are discussed with their partners, so the quality of their answers will be better. Students will also be more confident to present the results of discussions they have practiced with their partners. Students are also required to cooperate with each other in understanding a material because the success of group learning is determined by the learning outcomes of each group member.

In the first hypothesis testing, the test criterion is accept $\mathrm{H}_{\mathrm{o}}$ if $-\mathrm{t}_{\text {table }}<\mathrm{t}_{\text {count }}<\mathrm{t}_{\text {table. }}$. $\mathrm{H}_{\mathrm{o}}$ reads learning outcomes using concept maps in cooperative learning are the same as learning outcomes using concept maps in conventional. The calculation of the first hypothesis $t_{\text {count }}=3.042$ and $t_{\text {table }}=1.995$. $t_{\text {count }}$ is not between $-t_{\text {table }}$ and $t_{\text {table }}$, means $H_{o}$ rejected, it can be concluded that the learning outcomes of students taught using concept maps through cooperative learning TPS signicantly different from learning outcomes of students taught with concept maps through conventional learning.

3.3 Learning outcomes high initial knowledge students of experiment and control classes. 


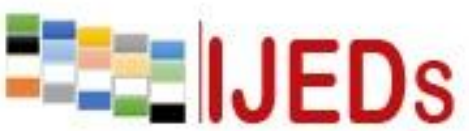

http://ijeds.ppj.unp.ac.id/index.php/IJEDS
International Journal of Educational Dynamics

Vol. 2 No. 1 (pp. 234-243) Desember 2019

p_ISSN 2655-4852

e_ISSN 2655-5093

Table 5. Learning outcomes data high initial knowledge students of experiment and control classes

\begin{tabular}{|c|c|c|c|c|c|c|}
\hline Group & $\bar{X}$ & $\mathrm{~S}$ & $\mathrm{X}_{\max }$ & $\mathrm{X}_{\min }$ & $\mathrm{t}_{\text {count }}$ & $\mathrm{t}_{\text {table }}$ \\
\hline Experiment & 86.06 & 9.57 & 100 & 65 & \multirow{2}{*}{2.742} & \multirow{2}{*}{2.032} \\
\hline Control & 77.11 & 11.31 & 96 & 54 & & \\
\hline
\end{tabular}

Table 5 shows that the average value of the learning outcomes high initial knowledge of experiment class students who were taught using concept map through TPS cooperative learning was higher than high initial knowledge control class students who were taught using concept map through conventional learning. The average value student of the experiment group was 86.06 and the control group was 77.11.

Initial knowledge is one of the determining factors in understanding and applying a concept. One of Ausubel's theories states that the most important factor influencing learning is what students already know (initial knowledge). A concept must be linked to concepts that already exist in students' cognitive structures so that learning becomes meaningful. The use of concept maps in cooperatif learning TPS can be use to find out and develop students' knowledge. The result show that students with high initial knowledge taught with concept map through cooperative learning TPS get higher learning outcomes compared to students with high initial knowledge control class students who were taught using concept maps through conventional learning.

Cooperative learning emphasizes the interaction of synergy, positive interdependence, individual responsibility and cooperation between groups to learn a material. Students who have high initial knowledge will more easily accept and form new knowledge. Student with high initial knowledge can easily explain and repeat concepts that are being learned when helping friends in study groups. Students with high initial knowledge also can improve their ability to interact and express opinions and encourage significant improvement in learning outcomes.

In the second hypothesis testing, the test criterion is accept Ho if $\mathrm{t}_{\text {table }}<\mathrm{t}_{\text {count }}<\mathrm{t}_{\text {table. }} \mathrm{H}_{\mathrm{o}}$ reads learning outcomes high initial knowledge using concept maps in cooperative learning are the same as learning outcomes high initial knowledge using concept maps in conventional. The calculation of the second hypothesis $t_{\text {count }}=2.742$ and $t_{\text {table }}=2.032$. $t_{\text {count }}$ is not between $-t_{\text {table }}$ and $t_{\text {table }}$, means $H_{o}$ rejected, it can be concluded that the learning outcomes high initial knowledge of students taught using 


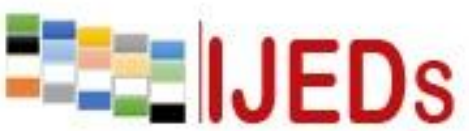

http://ijeds.ppj.unp.ac.id/index.php/IJEDS
International Journal of Educational Dynamics

Vol. 2 No. 1 (pp. 234-243) Desember 2019

p_ISSN 2655-4852

e_ISSN 2655-5093

concept maps through cooperative learning TPS signicantly different from learning outcomes high initial knowledge of students taught with concept maps through conventional learning.

3.4 Learning outcomes low initial knowledge students of experiment control classes.

Table 6. learning outcomes data low initial knowledge students of experiment and control classes

\begin{tabular}{|c|c|c|c|c|c|c|}
\hline Group & $\bar{X}$ & $\mathrm{~S}$ & $\mathrm{X}_{\max }$ & $\mathrm{X}_{\min }$ & $\mathrm{t}_{\text {count }}$ & $\mathrm{t}_{\text {table }}$ \\
\cline { 1 - 5 } Experiment & 72.28 & 8.01 & 81 & 58 & \multirow{2}{*}{2.606} & \multirow{2}{*}{2.032} \\
\cline { 1 - 5 } Control & 63.89 & 11.09 & 81 & 50 & & \\
\hline
\end{tabular}

Table 6 shows that the average value of the learning outcomes low initial knowledge of experiment class students who were taught using concept map through TPS cooperative learning was higher than low initial knowledge control class students who were taught using concept map through conventional learning. The average value student of the experiment group was 72.28 and the control group was 63.89 .

Student with low initial knowledge can learn with high initial knowledge student who are in their study groups or known as peer tutors. Student with low initial knowledge and student with high initial knowledge must be able to work together in their dtudy groups because individual learning outcomes will affect their group learning outcomes. This proves that the use of concept map through cooperative learning TPS can make students learn better for students with low initial knowledge and students with high initial knowledge. Learning with concept map through cooperative TPS makes student do more so that the learning is not just memorizing but learning is meaningful so that the student learning outcomes improve.

In the third hypothesis testing, the test criteria is accept $\mathrm{H}_{\mathrm{o}}$ if $-\mathrm{t}_{\text {table }}<\mathrm{t}_{\text {count }}<\mathrm{t}_{\text {table }}$. $\mathrm{H}_{\mathrm{o}}$ reads learning outcomes low initial knowledge using concept map in cooperative learning are the same as learning outcomes low initial knowledge using concept maps in conventional. The calculation of the second hypothesis $t_{\text {count }}=2.606$ and $t_{\text {table }}=2.032$. $t_{\text {count }}$ is not between $-t_{\text {table }}$ and $t_{\text {table }}$, means $H_{o}$ rejected, it can be concluded that the learning outcomes low initial knowledge of students taught using concept map through cooperative learning TPS signicantly different from learning outcomes low initial knowledge of students taught with concept maps through conventional learning. 


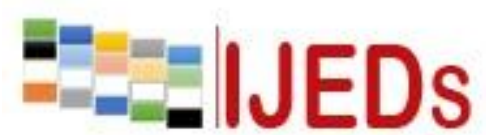

http://ijeds.ppj.unp.ac.id/index.php/IJEDS
International Journal of Educational Dynamics

Vol. 2 No. 1 (pp. 234-243) Desember 2019

p_ISSN 2655-4852

e_ISSN 2655-5093

\section{CONCLUSION}

The conclusion based on the data analisys is there is an influence of the use of concept map in cooperative learning Think Pair Share (TPS) on the learning outcomes on eleventh grade science student in SMAN 1 Dua Koto Pasaman. Based on the average value of student learning outcomes in the experiment group, $75 \%$ or 27 students have reached the minimum completeness criteria. The calculation of the hypothesis $t_{\text {count }}=$ 3.042 and $t_{\text {table }}=1.995$. $t_{\text {count }}$ is not between $-t_{\text {tables }}$ and $t_{\text {tables }}$, means $H_{o}$ rejected, it can be concluded that the learning outcomes of students taught using concept maps through cooperative learning TPS signicantly different from learning outcomes of students taught with concept maps through conventional learning. Learning with concept maps guides students in understanding lessons through exiting concept. The use of concept maps with cooperative learning TPS can improve student learning outcomes because it can encourage students to think more, discuss with partners, and share answers with classmates.

\section{REFERENCES}

Agustin, A. 2018. Pengaruh Penggunaan Peta Konsep berbasis Multilevel terhadap Pemahaman Konsep Kimia Siswa. Journal of Chemistry in Education. CiE 7 (2) $8-13$.

Asmaningrum, H.P. 2018. Penerapan Media Peta Konsep Terhadap Hasil Belajar Siswa SMA Geradus Adii Merauke. Jurnal Inovasi Pendidikan Kimia. Vol 12 No 2. 2224-2238Dahar, Ratna Wilis. 1996. Teori-Teori Belajar. Jakarta : Erlangga.

Santoso,T \& Supriadi. 2014. Pembelajaran Penalaran Argumen Berbasis Peta Konsep untuk Meningkatkan Pemahaman Konsep Kimia. In Prosiding Seminar Nasional Kimia.

Sudjana. 1996. Metoda Statistik. Bandung : Transito.

Trianto. 2010. Mendesain Model Pembelajaran Inovatif-Progresif. Jakarta : Kencana Prenada Media Group.

Wibowo, T. 2008. Psikologi Pendidikan. Jakarta : Kencana Prenada Media Grup 